
\title{
$\begin{array}{ll}\text { Research Square } & \begin{array}{l}\text { Preprints are preliminary reports that have not undergone peer review. } \\ \text { They should not be considered conclusive, used to inform clinical practice, } \\ \text { or referenced by the media as validated information. }\end{array}\end{array}$
}

\section{Immunogenicity of COVID-19 mRNA Vaccines in Immunocompromised Patients: A Systematic Review and Meta-Analysis}

Mohammad-Mehdi Mehrabinejad

Tehran University of Medical Sciences School of Medicine

Fatemeh Moosaie

Tehran University of Medical Sciences School of Medicine

Hojat Dehghanbanadaki

Tehran University of Medical Sciences School of Medicine

Abdolkarim Hajighadery

Tehran University of Medical Sciences School of Medicine

\section{Mahya Shabani}

Tehran University of Medical Sciences School of Medicine

\section{Mohammadreza Tabary}

University of Pittsburgh School of Medicine

Armin Aryannejad

Tehran University of Medical Sciences School of Medicine

SeyedAhmad SeyedAlinaghi

Tehran University of Medical Sciences School of Medicine

Nima Rezaei ( $\sim$ rezaei_nima@yahoo.com)

Tehran University of Medical Sciences

\section{Research Article}

Keywords: COVID-19, SARS-CoV-2, Vaccination, Immunocompromised patient, Malignancy, Transplantation, Autoimmune, Efficacy

Posted Date: November 17th, 2021

DOI: https://doi.org/10.21203/rs.3.rs-994503/v1

License: @ (1) This work is licensed under a Creative Commons Attribution 4.0 International License. Read Full License 


\section{Abstract \\ Background}

Immunocompromised (IC) patients are at higher risk of severe SARS-CoV-2 infection, morbidity, and mortality compared to general population. They should be prioritized for primary prevention through vaccination. In this study, we aimed to evaluate the efficacy of COVID-19 mRNA vaccines in IC patients through a systematic review and meta-analysis approach.

\section{Method}

PubMed-MEDLINE, Scopus, and Web of Science were searched for original articles reporting the immunogenicity of two doses of mRNA COVID-19 vaccines in adult patients with IC condition between June 1, 2020 and September 1, 2021. Meta-analysis was performed using either random or fixed effect according to the heterogeneity of the studies. Subgroup analysis was performed to identify potential sources of heterogeneity.

\section{Results}

A total of 26 studies on 3207 IC patients and 1726 healthy individuals were included. The risk of seroconversion in IC patients was $48 \%$ lower than those in controls ( $R R=0.52[0.42,0.65]$ ). IC patients with autoimmune condition were $54 \%$ and patients with malignancy were $42 \%$ more likely to have positive seroconversion compared to those with transplant $(P<0.01)$. Subgroup meta-analysis based on type of malignancy, revealed significantly higher proportion of positive seroconversion in solid organ compared to hematologic malignancies (RR=0.88 [0.85, 0.92] vs. $0.61[0.44,0.86], P=0.03)$. Subgroup meta-analysis based on type of transplantation (kidney vs. others), showed no statically significant between group difference of seroconversion $(P=0.55)$.

\section{Conclusions}

IC patients, especially transplant patients, developed lower immunogenicity with two-dose of COVID-19 mRNA vaccines. Among patients with IC, those with autoimmune condition and solid organ malignancies are mostly benefited from COVID-19 vaccination. Findings from this meta-analysis, could aid health care policy makers upon making decision regarding the importance of the booster dose or more strict personal protections in the IC patients.

\section{Introduction}

Immunocompromised (IC) conditions are estimated to affect approximately $2.7 \%$ of United States adults (1). Such patients are at higher risk of severe SARSCoV-2 infection, extended hospitalization, intensive care admission, and mortality compared to general population (2-6). Besides, prolonged viral shedding and potential sources of novel SARS-CoV-2 variants in this population are also of particular importance (7-9). Thus, IC patients should be prioritized for primary prevention through Coronavrus infectious disease 2019 (COVID-19) vaccination.

Global efforts have been taken to develop SARS-CoV-2 vaccines since the initiation of the current COVID-19 pandemic. The mRNA vaccines (i.e., mRNA-1273 and BNT162b2) are the most commonly approved vaccines worldwide which are utilized in different clinical trials in global scale (10). The overall efficacy and safety of COVID-19 vaccines in phase III trials were promising (11), sparking global hope toward ending the current outbreak. However, the application of COVID-19 vaccines in patients with impaired immune system remains as an ongoing subject of debate as they were excluded from the original trials (12,13). IC patients due to either the primary disease or the immunosuppressive treatments are more likely to show weak or suboptimal immune response to COVID-19 vaccines given previous studies on influenza vaccines (14). Hence, the real-world statistics regarding the efficacy of COVID-19 vaccines are required to provide physicians a better insight towards decision-making in this group of high-risk patients.

In this study, we aimed to systematically review the literature and analyze the pooled effectiveness of COVID-19 vaccination in IC patients compared to healthy controls using meta-analysis. We also assessed the efficacy of mRNA vaccines in IC patients based on their etiological factor including malignancy, transplantation, and autoimmune diseases.

\section{Methods And Materials Protocol and Literature search}

This systematic review and meta-analysis was conducted according to the Preferred Reporting Items for Systematic Reviews and Meta-Analyses (PRISMA) guidelines.

PubMed-MEDLINE, Scopus, and Web of Science were searched for original articles reporting the efficacy in adult patients with IC condition between June 1, 2020 and September 1, 2021. The search terms were as follows: ((COVID-19) OR (SARS-CoV-2) OR (novel coronavirus)) AND ((vaccine) OR (vaccination)) OR (vaccinated)) AND ((immunocompromised) OR (immunosuppressed) OR (corticosteroid) OR (chemotherapy) OR (cancer) OR (malignancy) OR (rheumatologic disease) OR (immunodeficiency) OR (autoimmune) OR (AIDS) OR (HIV) OR (transplant)).

The references of the selected articles were further screened to search for potentially relevant articles. Two reviewers independently performed the literature search, and any disagreement regarding study inclusion was resolved by consensus. The authors were not blinded to the authors, institutions, or journals while selecting studies or extracting data. EndNote version X9 was used for literature management.

Page $2 / 12$ 


\section{Eligibility criteria}

Studies investigating the immunogenicity of COVID-19 mRNA vaccination in IC patients were eligible for inclusion. The included studies met the following criteria: (1) Population: studies on IC patients with a sample size $\geq 30$ participants and control group of healthy individuals. IC patients included patients with solid organ or hematologic malignancies who receive chemotherapy, patients with inherited or acquired immunodeficiency diseases, patients with autoimmune or rheumatologic diseases, patients with other conditions (i.e., asthma) receiving long-term corticosteroid, and transplant recipients. (2) Intervention: mRNA COVID-19 vaccination (3) Study design: all retrospective and prospective studies as well as clinical trials with healthy control group were included. (4) Outcomes: main outcome of this study was seroconversion in IC patients using anti-SARS-CoV-2 spike IgG $\geq 14$ days after the second dose of COVID-19 mRNA vaccines. The subgroup analysis was performed to determine the efficacy of COVID-19 mRNA vaccines in different groups of patients based on etiology of IC condition.

The exclusion criteria were as follows: (1) reviews and editorials; (2) case reports or case series <30 patients; (3) partially overlapping patient cohorts; (4) articles not written in English; (5) single-arm studies or with non-healthy control group; and (6) non-human studies. Two reviewers independently reviewed the literature in consensus.

\section{Data Collection}

Eligible studies were evaluated by two experts independently and the following data was extracted from each included publication: author, date of publications, country of origin, study design, study sample size, definition of IC conditions, inclusion and exclusion criteria, the number of IC patients, variables matched, the proportion of male, mean age, duration of disease, type and etiology of the immunodeficiency and its proportion to the total population, type of vaccination, and efficacy of the vaccination.

Any conflicts in data extraction were discussed or consulted by a third expert and resolved.

\section{Quality assessment}

National Institutes of Health ( $\mathrm{NIH})$ quality assessment tool (15) to evaluate the included studies. The scores of 11-14, 6-10, and 0-5 were considered as good, fair, and poor quality, respectively. Moreover, the studies were evaluated in terms of methodology by two experts, independently; any conflict of opinion was discussed or referred to third expert and resolved.

\section{Statistical analyses}

STATA version 16 for Windows (Stata Corp, College Station, Texas) was utilized for the meta-analysis. At least three studies in each group were required to synthesize the data on outcomes. The heterogeneity of studies was measured using $\mathrm{I}^{2}$ or $\mathrm{Q}$ test. A fixed model was employed, if the heterogeneity of studies was below $40 \%$ and a random effect model in case of heterogeneity above $40 \%$. Effect measures were calculated. Also, based on the heterogeneity of studies, either meta-regression analysis or subgroup analysis was performed for potential moderators. Moreover, funnel plot asymmetry and the Eggers test were used to assess publication bias. In case of significant publication bias, the adjustment was performed for the effect size using the trim and fill method. A $P$-value less than 0.05 was considered statistically significant.

\section{Results}

\section{Study selection}

The study selection flowchart is presented in Figure 1. The literature search, after removing duplicates, resulted in 2093 studies, of which 1992 were considered irrelevant following title and abstract screening. Of the remaining 101, a further 75 were removed according to the exclusion criteria. Therefore, in total, 26 studies (16-41) were eligible for the meta-analysis of seroconversion after the second dose of the vaccine.

\section{Characteristics of included studies}

Characteristics of the included studies are provided in Table 1 . All 26 included studies on 3207 IC patients and 1726 healthy controls showed that $65.8 \%$ IC patients and $99.2 \%$ healthy controls had seropositive IgG test following second dose of COVID-19 mRNA vaccines. All of the studies were conducted in 2021. Sample sizes, from which relevant data were available for extraction, varied from 40 to 807 . Participants' mean age ranged from 42 to 71.4 years. The majority of the studies $(18,20,23-25,27,29-34,36-41)$ had a prospective cohort design $(n=18)$. Five studies $(17,19,21,22,28)$ had a retrospective cohort design and three $(16,26,35)$ were cross-sectional. 
Table 1

Details of the data presented by the included studies.

\begin{tabular}{|c|c|c|c|c|c|c|c|c|c|c|c|}
\hline \multirow{2}{*}{$\begin{array}{l}\text { Study (First } \\
\text { Author) }\end{array}$} & \multirow[t]{2}{*}{ Country } & \multirow[t]{2}{*}{ Study design } & \multirow{2}{*}{$\begin{array}{l}\text { Total } \\
\text { sample } \\
\text { size }\end{array}$} & \multicolumn{3}{|l|}{ Case } & \multicolumn{3}{|l|}{ Control } & \multirow{2}{*}{$\begin{array}{l}\text { Etiology of } \\
\text { IC condition }\end{array}$} & \multirow[t]{2}{*}{ Type of vaccine } \\
\hline & & & & $\begin{array}{l}\text { No of } \\
\text { cases }\end{array}$ & $\begin{array}{l}\text { Male\% } \\
\text { of } \\
\text { cases }\end{array}$ & Age & $\begin{array}{l}\text { No of Non- } \\
\text { cases (if } \\
\text { applicable) }\end{array}$ & $\begin{array}{l}\text { Male\% } \\
\text { of } \\
\text { Non- } \\
\text { cases }\end{array}$ & Age & & \\
\hline Sattler A & Germany & $\begin{array}{l}\text { Prospective } \\
\text { Cohort }\end{array}$ & 78 & 39 & 71.8 & 57.3 & 39 & 51.2 & 53.0 & Transplant & $\begin{array}{l}\text { BNT162b2 } \\
\text { (Pfizer/BionTech) }\end{array}$ \\
\hline $\begin{array}{l}\text { Rincon- } \\
\text { Arevalo H }\end{array}$ & Germany & $\begin{array}{l}\text { Prospective } \\
\text { Cohort }\end{array}$ & 75 & 40 & 70 & $\begin{array}{l}62.4 \\
{[51.2-} \\
69.5]^{\star}\end{array}$ & 35 & 57.1 & $\begin{array}{l}51 \\
{[34-} \\
80]^{*}\end{array}$ & Transplant & $\begin{array}{l}\text { BNT162b2 } \\
\text { (Pfizer/BionTech) }\end{array}$ \\
\hline Korth J & Germany & $\begin{array}{l}\text { Prospective } \\
\text { Cohort }\end{array}$ & 46 & 23 & 48 & 57.7 & 23 & 39 & 44.4 & Transplant & $\begin{array}{l}\text { BNT162b2 } \\
\text { (Pfizer/BionTech) }\end{array}$ \\
\hline $\begin{array}{l}\text { Rabinowich } \\
\mathrm{L}\end{array}$ & Israel & $\begin{array}{l}\text { Cross- } \\
\text { sectional }\end{array}$ & 105 & 80 & 70 & 60.1 & 25 & 32 & 52.7 & Transplant & $\begin{array}{l}\text { BNT162b2 } \\
\text { (Pfizer/BionTech) }\end{array}$ \\
\hline Schramm R & Germany & $\begin{array}{l}\text { Prospective } \\
\text { Cohort }\end{array}$ & 100 & 50 & 64 & 55 & 50 & 34 & 47 & Transplant & $\begin{array}{l}\text { BNT162b2 } \\
\text { (Pfizer/BionTech) }\end{array}$ \\
\hline Cao J & USA & $\begin{array}{l}\text { Retrospective } \\
\text { Cohort }\end{array}$ & 47 & 37 & 72.9 & $\begin{array}{l}64[50- \\
69]^{\star}\end{array}$ & 10 & 20 & $\begin{array}{l}66 \\
{[57-} \\
75]^{\star}\end{array}$ & Transplant & $\begin{array}{l}\text { mRNA-1273 } \\
\text { (Moderna) or } \\
\text { BNT162b2 } \\
\text { (Pfizer/BionTech) }\end{array}$ \\
\hline Grupper A & Israel & $\begin{array}{l}\text { Retrospective } \\
\text { Cohort }\end{array}$ & 151 & 136 & 81.7 & 58.6 & 25 & 32 & 52.7 & Transplant & $\begin{array}{l}\text { BNT162b2 } \\
\text { (Pfizer/BionTech) }\end{array}$ \\
\hline Marinaki S & Greece & $\begin{array}{l}\text { Prospective } \\
\text { Cohort }\end{array}$ & 150 & 34 & 79.4 & $\begin{array}{l}60[49.1- \\
68.4]^{\star}\end{array}$ & 116 & - & - & Transplant & $\begin{array}{l}\text { BNT162b2 } \\
\text { (Pfizer/BionTech) }\end{array}$ \\
\hline $\begin{array}{l}\text { Rashidi- } \\
\text { Alavijeh J }\end{array}$ & Germany & $\begin{array}{l}\text { Prospective } \\
\text { Cohort }\end{array}$ & 63 & 43 & 60.5 & $\begin{array}{l}57[49- \\
64]^{\star}\end{array}$ & 20 & 45 & $\begin{array}{l}43.5 \\
{[38-} \\
53.5]^{\star}\end{array}$ & Transplant & $\begin{array}{l}\text { BNT162b2 } \\
\text { (Pfizer/BionTech) }\end{array}$ \\
\hline $\operatorname{Hod} \mathrm{T}$ & Israel & $\begin{array}{l}\text { Prospective } \\
\text { Cohort }\end{array}$ & 322 & 120 & 80 & 59.7 & 141 & 30.2 & 57.04 & Transplant & $\begin{array}{l}\text { BNT162b2 } \\
\text { (Pfizer/BionTech) }\end{array}$ \\
\hline \multirow[t]{2}{*}{ Stumpf J } & Germany & $\begin{array}{l}\text { Prospective } \\
\text { Cohort }\end{array}$ & 512 & 368 & 65.5 & 57.3 & 144 & 23.6 & 48 & Transplant & $\begin{array}{l}\text { (a) mRNA-1273 } \\
\text { (Moderna) } \\
\text { (n=143); }\end{array}$ \\
\hline & & & & & & & & & & & $\begin{array}{l}\text { (b) BNT162b2 } \\
\text { (Pfizer/BionTech) } \\
(\mathrm{n}=369)\end{array}$ \\
\hline Firket L & USA & $\begin{array}{l}\text { Retrospective } \\
\text { Cohort }\end{array}$ & 40 & 20 & 45 & 51.2 & 20 & 65 & 48.3 & Transplant & $\begin{array}{l}\text { BNT162b2 } \\
\text { (Pfizer/BionTech) }\end{array}$ \\
\hline Peled Y & Israel & $\begin{array}{l}\text { Prospective } \\
\text { Cohort }\end{array}$ & 213 & 77 & 64 & $\begin{array}{l}62[49- \\
68]^{*}\end{array}$ & 136 & 37 & 63 & Transplant & $\begin{array}{l}\text { BNT162b2 } \\
\text { (Pfizer/BionTech) }\end{array}$ \\
\hline Monin L & UK & $\begin{array}{l}\text { Prospective } \\
\text { Cohort }\end{array}$ & 205 & 151 & 52 & $\begin{array}{l}73[64.5- \\
79.5]^{\star}\end{array}$ & 54 & 52 & $\begin{array}{l}40.5 \\
{\left[31.3^{-}\right.} \\
50]^{*}\end{array}$ & Malignancy & $\begin{array}{l}\text { BNT162b2 } \\
\text { (Pfizer/BionTech) }\end{array}$ \\
\hline Pimpinelli F & Italy & $\begin{array}{l}\text { Prospective } \\
\text { Cohort }\end{array}$ & 128 & 92 & $53 / 2$ & $70 *$ & 36 & 0 & 81 & Malignancy & $\begin{array}{l}\text { BNT162b2 } \\
\text { (Pfizer/BionTech) }\end{array}$ \\
\hline $\begin{array}{l}\text { Massarweh } \\
\text { A }\end{array}$ & Israel & $\begin{array}{l}\text { Prospective } \\
\text { Cohort }\end{array}$ & 180 & 102 & 57 & $\begin{array}{l}66[56- \\
72]^{\star}\end{array}$ & 78 & 32 & $\begin{array}{l}62 \\
{[49-} \\
70]^{*}\end{array}$ & Malignancy & $\begin{array}{l}\text { BNT162b2 } \\
\text { (Pfizer/BionTech) }\end{array}$ \\
\hline Agbarya A & Israel & $\begin{array}{l}\text { Cross- } \\
\text { sectional }\end{array}$ & 355 & 140 & 54 & 65.3 & 215 & 37.2 & 62.5 & Malignancy & $\begin{array}{l}\text { BNT162b2 } \\
\text { (Pfizer/BionTech) }\end{array}$ \\
\hline $\begin{array}{l}\text { Herishanu } \\
Y\end{array}$ & Israel & $\begin{array}{l}\text { Prospective } \\
\text { Cohort }\end{array}$ & 219 & 167 & 67.1 & $\begin{array}{l}71[63- \\
76]^{\star}\end{array}$ & 52 & - & $\begin{array}{l}69 \\
{[63-} \\
73.7]^{*}\end{array}$ & Malignancy & $\begin{array}{l}\text { BNT162b2 } \\
\text { (Pfizer/BionTech) }\end{array}$ \\
\hline lacono D & Italy & $\begin{array}{l}\text { Cross- } \\
\text { sectional }\end{array}$ & 108 & 36 & 41.6 & $82^{*}$ & 72 & - & $\geq 66$ & Malignancy & $\begin{array}{l}\text { BNT162b2 } \\
\text { (Pfizer/BionTech) }\end{array}$ \\
\hline Malard F & France & $\begin{array}{l}\text { Retrospective } \\
\text { Cohort }\end{array}$ & 225 & 195 & 60 & $68.9 *$ & 30 & - & - & Malignancy & $\begin{array}{l}\text { BNT162b2 } \\
\text { (Pfizer/BionTech) }\end{array}$ \\
\hline $\begin{array}{l}\text { Eliakim-Raz } \\
N\end{array}$ & Israel & $\begin{array}{l}\text { Prospective } \\
\text { Cohort }\end{array}$ & 161 & 95 & 58 & $\begin{array}{l}65[56- \\
72]^{*}\end{array}$ & 66 & 32 & $\begin{array}{l}62 \\
{[50-} \\
70]^{\star}\end{array}$ & Malignancy & $\begin{array}{l}\text { BNT162b2 } \\
\text { (Pfizer/BionTech) }\end{array}$ \\
\hline
\end{tabular}




\begin{tabular}{|c|c|c|c|c|c|c|c|c|c|c|c|}
\hline \multirow{2}{*}{$\begin{array}{l}\text { Study (First } \\
\text { Author) }\end{array}$} & \multirow[t]{2}{*}{ Country } & \multirow[t]{2}{*}{ Study design } & \multirow{2}{*}{$\begin{array}{l}\text { Total } \\
\text { sample } \\
\text { size }\end{array}$} & \multicolumn{3}{|l|}{ Case } & \multicolumn{3}{|l|}{ Control } & \multirow{2}{*}{$\begin{array}{l}\text { Etiology of } \\
\text { IC condition }\end{array}$} & \multirow{2}{*}{ Type of vaccine } \\
\hline & & & & $\begin{array}{l}\text { No of } \\
\text { cases }\end{array}$ & $\begin{array}{l}\text { Male\% } \\
\text { of } \\
\text { cases }\end{array}$ & Age & $\begin{array}{l}\text { No of Non- } \\
\text { cases (if } \\
\text { applicable) }\end{array}$ & $\begin{array}{l}\text { Male\% } \\
\text { of } \\
\text { Non- } \\
\text { cases }\end{array}$ & Age & & \\
\hline $\begin{array}{l}\text { Herzog } \\
\text { Tzarfati K }\end{array}$ & Israel & $\begin{array}{l}\text { Prospective } \\
\text { Cohort }\end{array}$ & 423 & 315 & 56 & $\begin{array}{l}71[61- \\
78]^{*}\end{array}$ & 108 & 44 & $\begin{array}{l}69 \\
{[58-} \\
74]^{\star}\end{array}$ & Malignancy & $\begin{array}{l}\text { BNT162b2 } \\
\text { (Pfizer/BionTech) }\end{array}$ \\
\hline Reuken P & Germany & $\begin{array}{l}\text { Prospective } \\
\text { Cohort }\end{array}$ & 55 & 28 & 46.4 & $\begin{array}{l}42[36- \\
59]^{*}\end{array}$ & 27 & - & - & Autoimmune & $\begin{array}{l}\text { BNT162b2 } \\
\text { (Pfizer/BionTech) }\end{array}$ \\
\hline Geisen UM & Germany & $\begin{array}{l}\text { Retrospective } \\
\text { Cohort }\end{array}$ & 68 & 42 & 35.7 & 50.5 & 26 & 30.8 & 37.5 & Autoimmune & $\begin{array}{l}\text { mRNA-1273 } \\
\text { (Moderna) or } \\
\text { BNT162b2 } \\
\text { (Pfizer/BionTech) }\end{array}$ \\
\hline Furer $\mathrm{V}$ & Israel & $\begin{array}{l}\text { Prospective } \\
\text { Cohort }\end{array}$ & 807 & 686 & 30.7 & $\begin{array}{l}59[19- \\
88]^{*}\end{array}$ & 121 & 35 & $50^{*}$ & Autoimmune & $\begin{array}{l}\text { BNT162b2 } \\
\text { (Pfizer/BionTech) }\end{array}$ \\
\hline $\begin{array}{l}\text { Prendecki } \\
\text { M }\end{array}$ & UK & $\begin{array}{l}\text { Prospective } \\
\text { Cohort }\end{array}$ & 155 & 85 & 52.1 & $\begin{array}{l}52[39.9- \\
63.9]^{*}\end{array}$ & 70 & - & $41.4^{*}$ & Autoimmune & $\begin{array}{l}\text { BNT162b2 } \\
\text { (Pfizer/BionTech) }\end{array}$ \\
\hline
\end{tabular}

\section{Quality assessment of included studies}

Quality assessment of the included studies is presented in Supplementary Table $\mathbf{S 1}$. The majority of the studies $(\mathrm{n}=18)(16-18,21-23,25,27,28,30,31,33$, $34,37-41)$ were of good quality and $8(19,20,24,26,29,32,35,36)$ had fair quality.

\section{Seroconversion in immunocompromised patients vs. controls}

Meta-analysis of 26 studies revealed that the risk of positive seroconversion in IC patients were $48 \%$ lower than healthy controls. (RR= $0.52 ; 95 \%$ Cl: $0.42,0.65$; $P<0.01)$. Subgroup meta-analysis based on type of IC (i.e. autoimmune, transplant, and malignancy), revealed a statistically significant between-group difference $(P<0.01)$ (Figure 2). When comparing each two subtypes of immunodeficiency, the results showed that IC patients due to transplant were less likely to develop positive seroconversion than IC patients due to autoimmune disorder $(P<0.01)$ as well as IC patients due to malignancy $(P<0.01)$. There was no statistically significant difference in seroconversion between IC patients with autoimmune disorder and those with malignancy $(P=0.19)$.

\section{Seroconversion in patients with autoimmune disease vs. controls}

Four $(20,21,34,37)$ of the included studies were conducted on IC patients with autoimmune immunodeficiency. Although the proportion of positive seroconversion in these patients was lower than the controls, the pooled analysis showed no statistically significant difference in relative risk of seroconversion between two groups. (RR=0.87; 95\% Cl: 0.75, 1.01; $P=0.07$ ) (Figure 2).

\section{Seroconversion in patients with malignancy vs. controls}

Meta-analysis of 9 studies $(16,18,23,24,26,28,30,31,33)$ revealed IC patients with malignancy were 0.75 times as likely to seroconvert than healthy controls (RR $=0.75 ; 95 \% \mathrm{Cl}: 0.63,0.89 ; P<0.01)$. Subgroup meta-analysis was conducted based on type of malignancy (hematologic vs. solid organ). Four $(23,24,28,33)$ of the studies were on patients with hematologic malignancy and three $(16,18,30)$ were on patients with solid organ malignancy. The relative risk of seroconversion among IC patients with solid organ was significantly higher than those with hematologic malignancies (RR= $0.88 ; 95 \%$ Cl: $0.85,0.92$ vs. $\mathrm{RR}=0.61 ; 95 \% \mathrm{Cl}: 0.44,0.86 ; P=0.0 .03$ ) (Figure 3 ).

\section{Seroconversion in transplant patients vs. controls}

Of the included studies, $13(17,19,22,25,27,29,32,35,36,38-41)$ were on IC patients with transplant. The meta-analysis showed transplant patients were $67 \%$ less likely to develop seroconversion than controls (RR= $0.33 ; 95 \% \mathrm{Cl}: 0.24,0.47 ; P<0.01)$. Seven $(19,22,25,27,38,39,41)$ of the included studies were on patients with kidney transplant and the remaining $(17,29,32,35,36,40)$ were on patients with different transplants; none of which with more than three studies to be separated in the subgroup analysis. Hence, subgroup meta-analysis was conducted based on type of transplantation (kidney vs. others). The analysis did not reveal any statistically significant difference in relative risk of seroconversion in patients with kidney transplant compared to other types of transplants (RR = 0.30; $95 \% \mathrm{Cl}: 0.20,0.47)$ vs. $\mathrm{RR}=0.38 ; 95 \% \mathrm{Cl}: 0.21,0.66 ; P=0.55)$ (Figure 4).

\section{Publication bias}

Funnel plot for seroconversion was asymmetrical and Egger test showed statistically significant evidence of publication bias $(P<0.01, z=-9.09)$. Trim and fill method was used to adjust the effect size (Pooled estimate $=0.87 ; 95 \% \mathrm{Cl}: 0.85,0.88$; number of studies $=84$ ) (Figure 5).

\section{Discussion}


Immunodeficiency comprises a wide range of disorders from primary (e.g., congenital) to numerous secondary conditions acquired consequently to a disease process or its treatment (e.g., human immunodeficiency virus (HIV) infection, radiation therapy, and immunosuppressive medications) (42). Although inconclusive, it has been shown that IC patients might be at a higher risk of severe COVID-19 $(43,44)$. On the other hand, limited number of studies revealed reduced vaccine efficacy of vaccines in IC patients (45). Nevertheless, data are limited on the efficacy of COVID-19 vaccines in this critical group of patients.

In this meta-analysis on the immunogenicity of COVID-19 mRNA vaccines in IC patients, we found lower risk of positive seroconversion in this group of patients compared to healthy controls. In addition, subgroup analysis revealed significantly lower risk of positive seroconversion in transplant patients in comparison with autoimmune disorder and patients with malignancy. Intriguingly, COVID-19 mRNA vaccines seem to achieve lower efficacy in patients with hematologic malignancies compared to solid organ.

We found significantly lower risk of positive seroconversion after the second dose of the vaccine in IC patients than controls. The controls were all healthy individuals, and this finding might not be surprising as observed with the administration of previous vaccines (e.g., Influenza vaccine) (46). However, it does not undermine the importance of vaccine in IC patients, as evidence highlights that the immune response after vaccines is more robust than that of natural SARS-CoV-2 infection $(47,48)$. It can also imply the importance of booster dose administration in this group of patients. As per recent Center for Disease Control and Prevention (CDC) guidelines, patients with moderately to severely compromised immune systems are recommended to receive an additional dose of COVID-19 mRNA vaccine (49). Furthermore, studies have shown the promotion of immune response in transplant patients receiving the third dose of mRNA vaccines, namely mRNA-1273 (Moderna) and BNT162b2 (Pfizer-BioNTech) $(50,51)$. However, a dichotomous view toward the booster dose seems to be insufficient since the degree and etiology of immunosuppression tend to be two important factors regarding immune response and the need for an additional dose (52). Whether a booster dose is necessarily associated with an enhanced immune response is also a matter of debate. There is evidence that initial postvaccine antibody titer was predictive of response to booster, and some IC patients will never mount an antibody response (53) and a more restricted personal protection is highly recommended even after vaccination (54).

Interestingly, our analysis revealed significantly lower relative risk of positive seroconversion in patients with transplant compared to patients with autoimmune disorder and patients with malignancy. A study by Evison et al., on the efficacy of Influenza vaccine showed that vaccine response rate was higher among patients with HIV and patients who received dialysis compared to renal transplant recipients and patients with rheumatologic disease (55). This can be justified by the fact that treatment regimen may be an important contributing factor. Mycophenolate mofetil has been shown to accompany less immune response compared to a regimen consisting of prednisone, cyclosporine, and azathioprine (56-58). These drugs which are used to prevent allograft rejection interfere with $\mathrm{T}$ and $\mathrm{B}$ cell activation and proliferation leading to impediment of antibody generation (59). Although we did find any significant difference between kidney transplant and other organ transplant recipients, transplant recipients seem to be more vulnerable to vaccine failures in general, and special attention should be directed toward this group of patients. Studies proposed some approach to increase immunogenicity of vaccine in transplant recipients such as modulation of immunosuppression, adjuvants, intradermal injection, high antigen doses, and booster administration (59).

Hematologic diseases are believed to have the highest level of immunosuppression amongst malignancies (60). This group of patients also 3-4-fold higher rates of severe/critical COVID-19 disease and mortality $(61,62)$. Hematologic malignancies are associated with immune dysfunction with alterations in both innate and adaptive immunity (63). Cytopenia, B/plasma cells reduction, hypogammaglobulinemia, anti-cancer therapy are amongst the underlying cause of immunodeficiency in these patients (64); thus, lower vaccine efficacy might be observed consequently, which is consistent with our findings about the lower immunogenicity of mRNA vaccines in patients with hematologic malignancies.

It is also worth mentioning that there are numerous approaches to the assessment of immune response after vaccine administration which are related to antiSARS-COV-2 recombinant spike, receptor binding domain or neutralizing IgG or total antibodies (52). We included articles with the main outcome of anti-SARSCoV-2 spike IgG level; however, seropositivity may not necessarily show protection against SARS-CoV-2 (53), and routine assessment COVID-19 vaccine responses is not recommended (53).

We confined this meta-analysis to mRNA vaccines due to limited studies on other COVID-19 vaccine types and to reduce heterogeneity. However, a study by Boekel et al., on the development of antibody in patients with autoimmune disease did not show any significant different between immunogenicity induced by an mRNA vaccine (BNT162b2) and a viral vector type (ChAdOx1 nCoV-19) (65). It has also been shown that inactivated COVID-19 vaccine (CoronaVac) can induce immune response in patients with immune-mediated disease; still, the titer of antibody is associated with age and type of immunosuppressive therapy (66).

This study indeed has some limitations. There was a lack data regarding HIV and other primary immunodeficiency disorders, and they are not included in this meta-analysis. Furthermore, we included studies with both retrospective and prospective design, which may reduce the level of evidence.

\section{Conclusion}

The risk of positive seroconversion in IC patients was almost half of those in healthy individuals. However, IC conditions due to autoimmune disorders did not lower the risk of positive seroconversion. Among IC conditions, transplantation induced lowest immunogenicity with $67 \%$ lower risk of seroconversion than healthy individuals. Besides, we found that vaccination among IC patients with hematological malignancy induced lower risk of seroconversion than those among IC patients with solid organ malignancy. Findings from this meta-analysis, could aid health care policy makers upon making decision regarding the importance of the booster dose or more strict personal protections in the IC patients.

\section{Abbreviations}

IC: Immunocompromised; COVID-19: Coronavrus infectious disease 2019; HIV: human immunodeficiency virus. 


\section{Declarations}

\section{Ethics approval and consent to participate}

Not applicable

\section{Consent for publication}

Not applicable

\section{Availability of data and materials}

The authors stated that all information provided in this article could be shared.

\section{Competing interests}

The authors declare that there is no conflict of interest regarding the publication of this manuscript.

\section{Funding}

This research did not receive any specific grant from funding agencies in the public, commercial, or not-for-profit sectors.

\section{Authors' contributions}

The conception and design of the study: MM, HD, SS, NR; acquisition of data: MM, AH, AA, MS, MT; drafting the article: MM, FM, MT; revising it critically for important intellectual content: SS, MM, NR, HD; final approval of the version to be submitted: NR, SS. All authors read and approved the final manuscript.

\section{Acknowledgements}

Not applicable

\section{References}

1. Harpaz R, Dahl RM, Dooling KL. Prevalence of immunosuppression among US adults, 2013. Jama. 2016;316(23):2547-8.

2. Abkhoo A, Shaker E, Mehrabinejad M-M, Azadbakht J, Sadighi N, Salahshour F. Factors Predicting Outcome in Intensive Care Unit-Admitted COVID-19 Patients: Using Clinical, Laboratory, and Radiologic Characteristics. Critical Care Research and Practice. 2021;2021.

3. Dumortier J, Duvoux C, Roux O, Altieri M, Barraud H, Besch C, et al. Covid-19 in liver transplant recipients: the French SOT COVID registry. Clinics research in hepatology gastroenterology. 2021;45(4):101639.

4. Liang W, Guan W, Chen R, Wang W, Li J, Xu K, et al. Cancer patients in SARS-CoV-2 infection: a nationwide analysis in China. The lancet oncology. 2020;21(3):335-7.

5. Alhumaid S, Al Mutair A, Al Alawi Z, Al Salman K, Al Dossary N, Omar A, et al. Clinical features and prognostic factors of intensive and non-intensive 1014 COVID-19 patients: an experience cohort from Alahsa, Saudi Arabia. Eur J Med Res. 2021;26(1):1-13.

6. SeyedAlinaghi S, Abbasian L, Solduzian M, Yazdi NA, Jafari F, Adibimehr A, et al. Predictors of the prolonged recovery period in COVID-19 patients: a cross-sectional study. Eur J Med Res. 2021;26(1):1-10.

7. Hensley MK, Bain WG, Jacobs J, Nambulli S, Parikh U, Cillo A, et al. Intractable COVID-19 and Prolonged SARS-CoV-2 Replication in a CAR-T-cell Therapy Recipient: A Case Study. Clinical infectious diseases:. an official publication of the Infectious Diseases Society of America; 2021.

8. Aydillo T, Gonzalez-Reiche AS, Aslam S, van de Guchte A, Khan Z, Obla A, et al. Shedding of viable SARS-CoV-2 after immunosuppressive therapy for cancer. New England journal of medicine. 2020;383(26):2586-8.

9. Avanzato VA, Matson MJ, Seifert SN, Pryce R, Williamson BN, Anzick SL, et al. Case study: prolonged infectious SARS-CoV-2 shedding from an asymptomatic immunocompromised individual with cancer. Cell. 2020;183(7):1901-12. e9.

10. Addeo A, Shah PK, Bordry N, Hudson RD, Albracht B, Di Marco M, et al. Immunogenicity of SARS-CoV-2 messenger RNA vaccines in patients with cancer. Cancer cell. 2021;39(8):1091-8. e2.

11. Cheng H, Peng Z, Luo W, Si S, Mo M, Zhou H, et al. Efficacy and Safety of COVID-19 Vaccines in Phase III Trials: A Meta-Analysis. Vaccines. 2021 ;9(6):582.

12. Polack FP, Thomas SJ, Kitchin N, Absalon J, Gurtman A, Lockhart S, et al. Safety and efficacy of the BNT162b2 mRNA Covid-19 vaccine. New England Journal of Medicine. 2020.

13. Baden LR, El Sahly HM, Essink B, Kotloff K, Frey S, Novak R, et al. Efficacy and safety of the mRNA-1273 SARS-CoV-2 vaccine. N Engl J Med. 2021;384(5):403-16.

14. Natori Y, Humar A, Lipton J, Kim D, Ashton P, Hoschler K, et al. A pilot randomized trial of adjuvanted influenza vaccine in adult allogeneic hematopoietic stem cell transplant recipients. Bone marrow transplantation. 2017;52(7):1016-21.

15. National Heart L, Institute B. Study Quality Assessment Tools [https://www. nhlbi. nih. Accessed; 2019. gov/health-topics/study-quality-assessment-tools].

16. Agbarya A, Sarel I, Ziv-Baran T, Agranat S, Schwartz O, Shai A, et al. Efficacy of the mRNA-Based BNT162b2 COVID-19 Vaccine in Patients with Solid Malignancies Treated with Anti-Neoplastic Drugs. Cancers. 2021;13(16). 
17. Cao J, Liu X, Muthukumar A, Gagan J, Jones P, Zu Y. Poor Humoral Response in Solid Organ Transplant Recipients following Complete mRNA SARS-CoV2 Vaccination. Clinical chemistry. 2021.

18. Eliakim-Raz N, Massarweh A, Stemmer A, Stemmer SM. Durability of Response to SARS-CoV-2 BNT162b2 Vaccination in Patients on Active Anticancer Treatment. JAMA oncology. 2021.

19. Firket L, Descy J, Seidel L, Bonvoisin C, Bouquegneau A, Grosch S, et al. Serological response to mRNA SARS-CoV-2 BNT162b2 vaccine in kidney transplant recipients depends on prior exposure to SARS-CoV-2. American journal of transplantation:. official journal of the American Society of Transplantation and the American Society of Transplant Surgeons; 2021.

20. Furer V, Eviatar T, Zisman D, Peleg H, Paran D, Levartovsky D, et al. Immunogenicity and safety of the BNT162b2 mRNA COVID-19 vaccine in adult patients with autoimmune inflammatory rheumatic diseases and in the general population: a multicentre study. Annals of the rheumatic diseases; 2021.

21. Geisen UM, Berner DK, Tran F, Sümbül M, Vullriede L, Ciripoi M, et al. Immunogenicity and safety of anti-SARS-CoV-2 mRNA vaccines in patients with chronic inflammatory conditions and immunosuppressive therapy in a monocentric cohort. Annals of the rheumatic diseases; 2021.

22. Grupper A, Rabinowich L, Schwartz D, Schwartz IF, Ben-Yehoyada M, Shashar M, et al. Reduced humoral response to mRNA SARS-CoV-2 BNT162b2 vaccine in kidney transplant recipients without prior exposure to the virus. American journal of transplantation: official journal of the American Society of Transplantation the American Society of Transplant Surgeons. 2021;21(8):2719-26.

23. Herishanu Y, Avivi I, Aharon A, Shefer G, Levi S, Bronstein Y, et al. Efficacy of the BNT162b2 mRNA COVID-19 vaccine in patients with chronic lymphocytic leukemia. Blood. 2021;137(23):3165-73.

24. Herzog Tzarfati K, Gutwein O, Apel A, Rahimi-Levene N, Sadovnik M, Harel L, et al. BNT162b2 COVID-19 vaccine is significantly less effective in patients with hematologic malignancies. American Journal of Hematology. 2021

25. Hod T, Ben-David A, Olmer L, Levy I, Ghinea R, Mor E, et al. Humoral Response of Renal Transplant Recipients to the BNT162b2 SARS-CoV-2 mRNA Vaccine Using Both RBD IgG and Neutralizing Antibodies. Transplantation. 2021.

26. Iacono D, Cerbone L, Palombi L, Cavalieri E, Sperduti I, Cocchiara RA, et al. Serological response to COVID-19 vaccination in patients with cancer older than 80 years. Journal of geriatric oncology. 2021.

27. Korth J, Jahn M, Dorsch O, Anastasiou OE, Sorge-Hadicke B, Eisenberger U, et al. Impaired Humoral Response in Renal Transplant Recipients to SARSCoV-2 Vaccination with BNT162b2 (Pfizer-BioNTech). Viruses-Basel. 2021;13(5).

28. Malard F, Gaugler B, Gozlan J, Bouquet L, Fofana D, Siblany L, et al. Weak immunogenicity of SARS-CoV-2 vaccine in patients with hematologic malignancies. Blood Cancer Journal. 2021;11(8).

29. Marinaki S, Adamopoulos S, Degiannis D, Roussos S, Pavlopoulou ID, Hatzakis A, et al. Immunogenicity of SARS-CoV-2 BNT162b2 vaccine in solid organ transplant recipients. American journal of transplantation: official journal of the American Society of Transplantation the American Society of Transplant Surgeons. 2021;21(8):2913-5.

30. Massarweh A, Eliakim-Raz N, Stemmer A, Levy-Barda A, Yust-Katz S, Zer A, et al. Evaluation of Seropositivity Following BNT162b2 Messenger RNA Vaccination for SARS-CoV-2 in Patients Undergoing Treatment for Cancer. JAMA oncology.

31. Monin L, Laing AG, Munoz-Ruiz M, McKenzie DR, Del Barrio ID, Alaguthurai T, et al. Safety and immunogenicity of one versus two doses of the COVID-19 vaccine BNT162b2 for patients with cancer: interim analysis of a prospective observational study. Lancet Oncology. 2021;22(6):765-78.

32. Peled Y, Ram E, Lavee J, Sternik L, Segev A, Wieder-Finesod A, et al. BNT162b2 vaccination in heart transplant recipients: Clinical experience and antibody response. The Journal of heart lung transplantation: the official publication of the International Society for Heart Transplantation. 2021;40(8):759-62.

33. Pimpinelli F, Marchesi F, Piaggio G, Giannarelli D, Papa E, Falcucci P, et al. Fifth-week immunogenicity and safety of anti-SARS-CoV-2 BNT162b2 vaccine in patients with multiple myeloma and myeloproliferative malignancies on active treatment: preliminary data from a single institution. $\mathrm{J}$ Hematol Oncol. 2021;14(1):81.

34. Prendecki M, Clarke C, Edwards H, Mclntyre S, Mortimer P, Gleeson S, et al. Humoral and T-cell responses to SARS-CoV-2 vaccination in patients receiving immunosuppression. Annals of the rheumatic diseases; 2021.

35. Rabinowich L, Grupper A, Baruch R, Ben-Yehoyada M, Halperin T, Turner D, et al. Low immunogenicity to SARS-CoV-2 vaccination among liver transplant recipients. Journal of hepatology. 2021;75(2):435-8.

36. Rashidi-Alavijeh J, Frey A, Passenberg M, Korth J, Zmudzinski J, Anastasiou OE, et al. Humoral Response to SARS-Cov-2 Vaccination in Liver Transplant Recipients-A Single-Center Experience. Vaccines. 2021;9(7)

37. Reuken PA, Andreas N, Grunert PC, Glöckner S, Kamradt T, Stallmach A. T cell response after SARS-CoV-2 vaccination in immunocompromised patients with inflammatory bowel disease. Journal of Crohn's \& colitis; 2021.

38. Rincon-Arevalo H, Choi M, Stefanski AL, Halleck F, Weber U, Szelinski F, et al. Impaired humoral immunity to SARS-CoV-2 BNT162b2 vaccine in kidney transplant recipients and dialysis patients. Sci Immunol. 2021;6(60).

39. Sattler A, Schrezenmeier E, Weber UA, Potekhin A, Bachmann F, Straub-Hohenbleicher H, et al. Impaired humoral and cellular immunity after SARS-CoV-2 BNT162b2 (tozinameran) prime-boost vaccination in kidney transplant recipients. The Journal of clinical investigation. 2021;131(14).

40. Schramm R, Costard-Jackle A, Rivinius R, Fischer B, Muller B, Boeken U, et al. Poor humoral and T-cell response to two-dose SARS-CoV-2 messenger RNA vaccine BNT162b2 in cardiothoracic transplant recipients. Clin Res Cardiol. 2021;110(8):1142-9.

41. Stumpf J, Siepmann T, Lindner T, Karger C, Schwöbel J, Anders L, et al. Humoral and cellular immunity to SARS-CoV-2 vaccination in renal transplant versus dialysis patients: A prospective, multicenter observational study using mRNA-1273 or BNT162b2 mRNA vaccine. The Lancet regional health Europe. 2021:100178. 
42. Duly K, Farraye FA, Bhat S. COVID-19 vaccine use in immunocompromised patients: A commentary on evidence and recommendations. American Journal of Health-System Pharmacy; 2021.

43. Fung M, Babik JM. COVID-19 in immunocompromised hosts: what we know so far. Clin Infect Dis. 2021;72(2):340-50.

44. Salahshour F, Mehrabinejad M-M, Toosi MN, Gity M, Ghanaati H, Shakiba M, et al. Clinical and chest CT features as a predictive tool for COVID-19 clinical progress: introducing a novel semi-quantitative scoring system. European Radiology. 2021:1-11.

45. Prevention CfDCa. Interim Clinical Considerations for Use of COVID-19 Vaccines Currently Approved or Authorized in the United States 2021 [Available from: https://www.cdc.gov/vaccines/covid-19/clinical-considerations/covid-19-vaccines-us.html.

46. Felldin M, Studahl M, Svennerholm B, Friman V. The antibody response to pandemic H1N1 2009 influenza vaccine in adult organ transplant patients. Transpl Int. 2012;25(2):166-71.

47. Altawalah H. Antibody Responses to Natural SARS-CoV-2 Infection or after COVID-19 Vaccination. Vaccines. 2021;9(8):910.

48. Greaney AJ, Loes AN, Gentles LE, Crawford KHD, Starr TN, Malone KD, et al. Antibodies elicited by mRNA-1273 vaccination bind more broadly to the receptor binding domain than do those from SARS-CoV-2 infection. Sci Transl Med. 2021;13:600.

49. Control CfD. Prevention. COVID-19 vaccines for moderately to severely immunocompromised people. Last Accessed September. 2021;7.

50. Hall VG, Ferreira VH, Ku T, lerullo M, Majchrzak-Kita B, Chaparro C, et al. Randomized trial of a third dose of mRNA-1273 vaccine in transplant recipients. New England Journal of Medicine. 2021.

51. Del Bello A, Abravanel F, Marion O, Couat C, Esposito L, Lavayssière L, et al. Efficiency of a boost with a third dose of anti-SARS-CoV-2 messenger RNAbased vaccines in solid organ transplant recipients. American Journal of Transplantation. 2021.

52. Lee ARYB, Wong SY, Chai LYA, Lee SC, Lee M, Muthiah MD, et al. Efficacy of COVID-19 vaccines in immunocompromised patients: A systematic review and meta-analysis. medRxiv. 2021.

53. Haidar G, Agha M, Lukanski A, Linstrum K, Troyan R, Bilderback A, et al. Immunogenicity of COVID-19 vaccination in immunocompromised patients: an observational, prospective cohort study interim analysis. medRxiv. 2021.

54. Tabatabaeizadeh S-A. Airborne transmission of COVID-19 and the role of face mask to prevent it: a systematic review and meta-analysis. Eur J Med Res. 2021;26(1):1-6.

55. Evison J, Farese S, Seitz M, Uehlinger DE, Furrer H, Mühlemann K. Randomized, double-blind comparative trial of subunit and virosomal influenza vaccines for immunocompromised patients. Clinical infectious diseases. 2009;48(10):1402-12.

56. Cavdar C, Sayan M, Sifil A, Artuk C, Yilmaz N, Bahar H, et al. The comparison of antibody response to influenza vaccination in continuous ambulatory peritoneal dialysis, hemodialysis and renal transplantation patients. Scand J Urol Nephrol. 2003;37(1):71-6.

57. Smith KG, Isbel NM, Catton MG, Leydon JA, Becker GJ, Walker RG. Suppression of the humoral immune response by mycophenolate mofetil. Nephrology Dialysis Transplantation. 1998;13(1):160-4.

58. Scharpé J, Evenepoel P, Maes B, Bammens B, Claes K, Osterhaus A, et al. Influenza vaccination is efficacious and safe in renal transplant recipients. Am J Transplant. 2008;8(2):332-7.

59. Caillard S, Thaunat O. COVID-19 vaccination in kidney transplant recipients. Nature Reviews Nephrology. 2021:1-3.

60. Chemaly RF, Ghosh S, Bodey GP, Rohatgi N, Safdar A, Keating MJ, et al. Respiratory viral infections in adults with hematologic malignancies and human stem cell transplantation recipients: a retrospective study at a major cancer center. Medicine. 2006;85(5):278-87.

61. Richardson S, Hirsch JS, Narasimhan M, Crawford JM, McGinn T, Davidson KW, et al. Presenting characteristics, comorbidities, and outcomes among 5700 patients hospitalized with COVID-19 in the New York City area. Jama. 2020;323(20):2052-9.

62. Wu Z, McGoogan JM. Characteristics of and important lessons from the coronavirus disease 2019 (COVID-19) outbreak in China: summary of a report of 72314 cases from the Chinese Center for Disease Control and Prevention. Jama. 2020;323(13):1239-42.

63. Atkins S, He F. Chemotherapy and beyond: infections in the era of old and new treatments for hematologic malignancies. Infectious Disease Clinics. 2019;33(2):289-309.

64. Dhodapkar MV, Dhodapkar KM, Ahmed R. Viral immunity and vaccines in hematologic malignancies: implications for COVID-19. Blood cancer discovery. 2021;2(1):9.

65. Boekel L, Steenhuis M, Hooijberg F, Besten YR, van Kempen ZL, Kummer LY, et al. Antibody development after COVID-19 vaccination in patients with autoimmune diseases in the Netherlands: a substudy of data from two prospective cohort studies. The Lancet Rheumatology. 2021.

66. Seyahi E, Bakhdiyarli G, Oztas M, Kuskucu MA, Tok Y, Sut N, et al. Antibody response to inactivated COVID-19 vaccine (CoronaVac) in immune-mediated diseases: a controlled study among hospital workers and elderly. Rheumatology international. 2021:1-12.

\section{Figures}




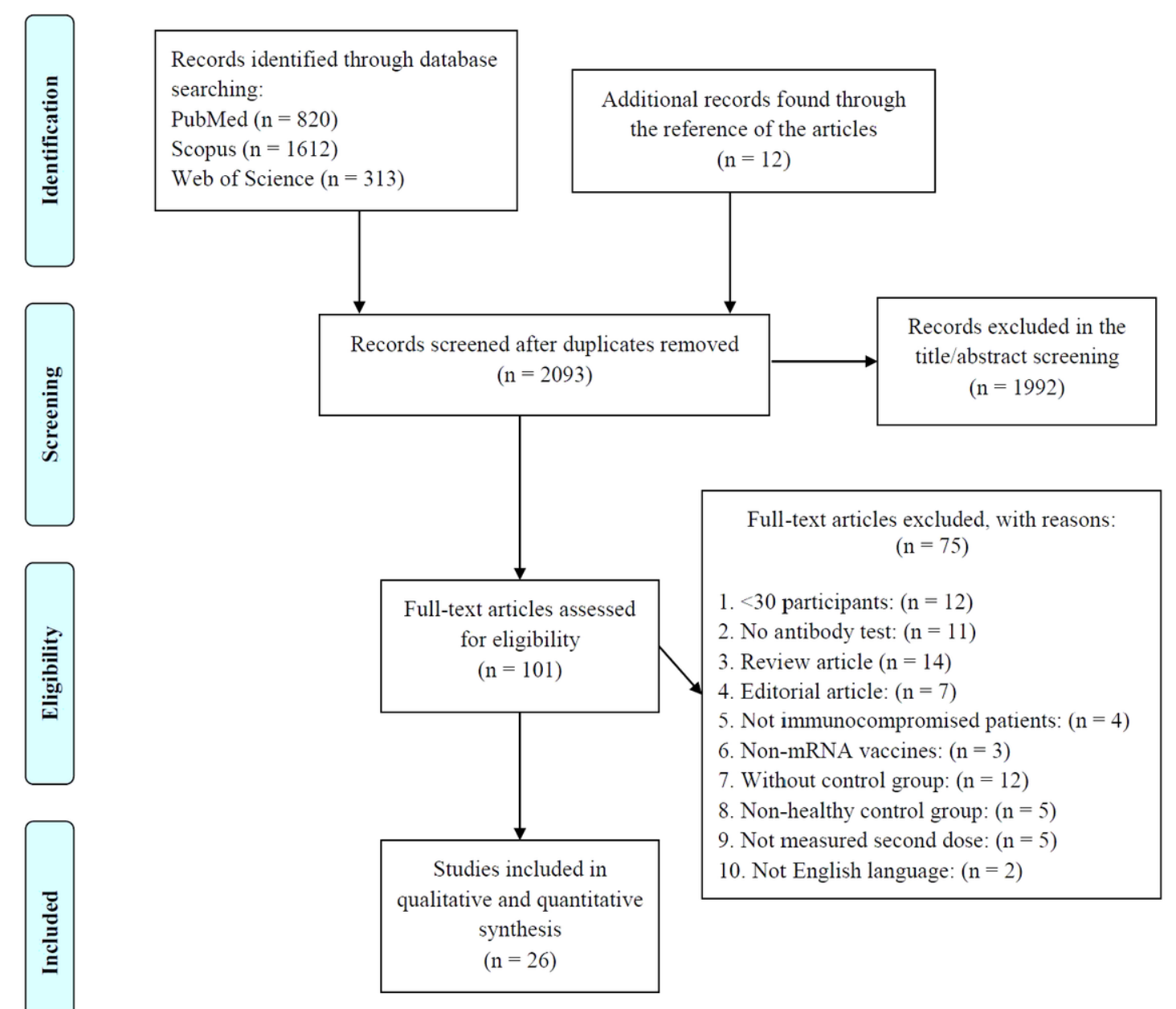

Figure 1

The PRISMA 2009 flow diagram of the study. 


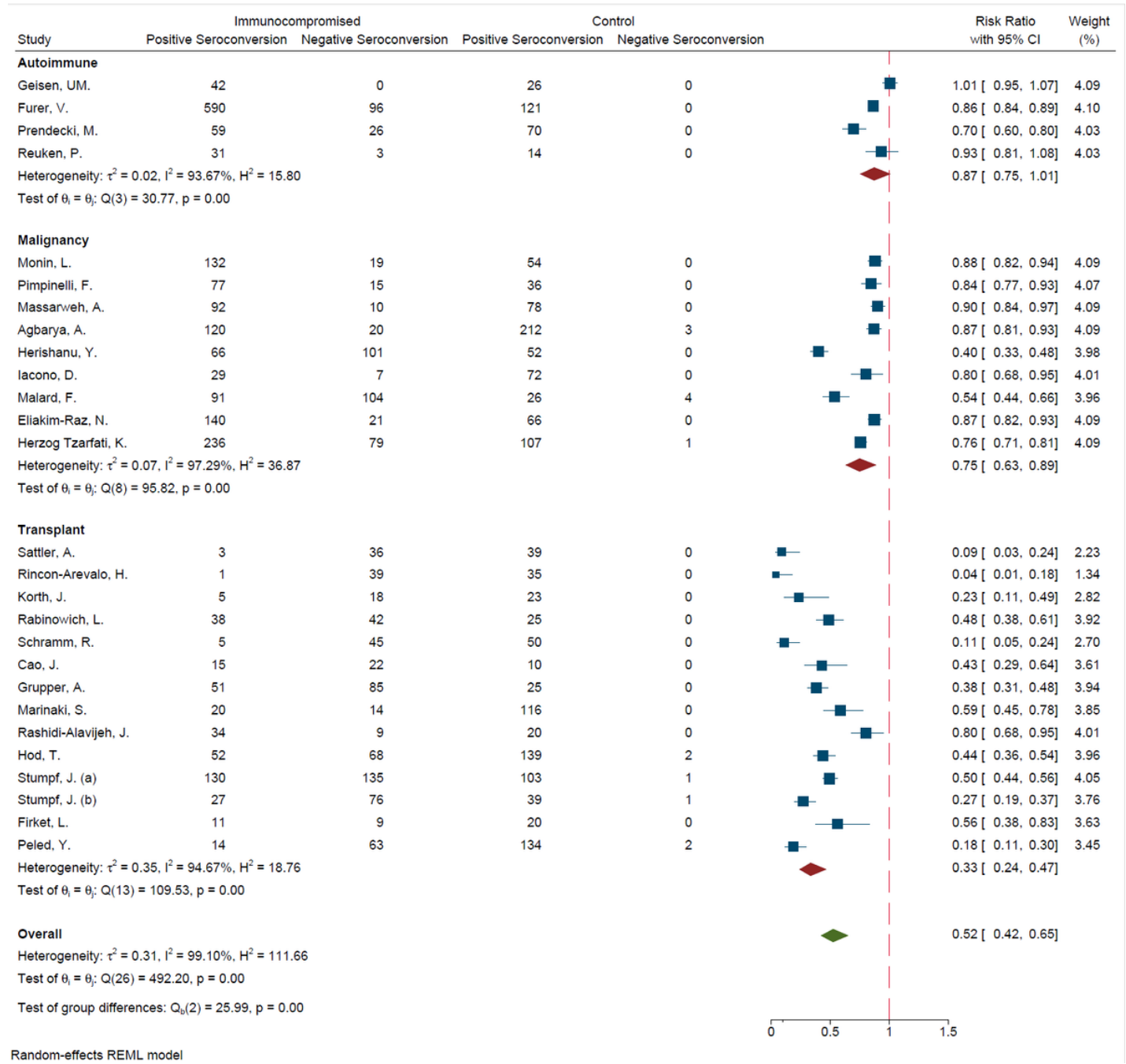

\section{Figure 2}

Meta-analysis of seroconversion in immunocompromised patients vs controls, based on type of immunodefeciency

Hematologic malignancy

Pimpinelli, F.

Herishanu, Y

\section{5}

101

104

Malard, F.

Herzog Tzarfati, K.

236

Heterogeneity: $\mathrm{T}^{2}=0.11, \mathrm{I}^{2}=96.79 \%, \mathrm{H}^{2}=31.13$

Test of $\theta_{i}=\theta_{j}: Q(3)=57.14, p=0.00$

\section{Solid organ malignancy}

\section{Massarweh, A.}

Agbarya, A.

92

120

Eliakim-Raz, N.

140

Heterogeneity: $T^{2}=0.00, I^{2}=0.03 \%, H^{2}=1.00$

Test of $\theta_{i}=\theta_{i}: Q(2)=0.75, p=0.69$

\section{Overall}

Heterogeneity: $\mathrm{T}^{2}=0.09, \mathrm{I}^{2}=97.92 \%, \mathrm{H}^{2}=48.08$

Test of $\theta_{i}=\theta_{j}: Q(6)=92.41, p=0.00$

Test of group differences: $Q_{b}(1)=4.49, p=0.03$

Random-effects REML model

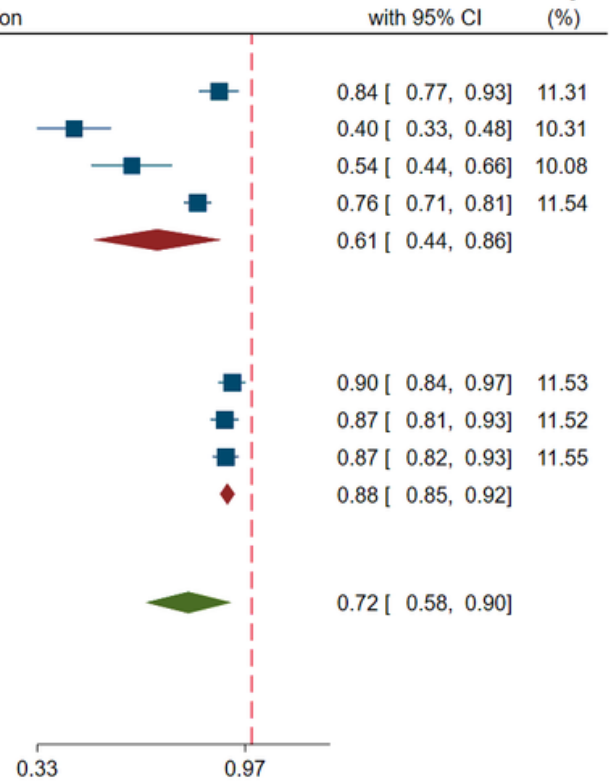

Figure 3

Meta-analysis of seroconversion in immunocompromised patients with malignancy vs controls, based on type of maliganacy 
Kidney transplant

Sattler, A.

Rincon-Arevalo, $\mathrm{H}$

$\begin{array}{rr}3 & 36 \\ 1 & 39 \\ 5 & 18 \\ 51 & 85 \\ 52 & 68 \\ 130 & 135 \\ 27 & 76 \\ 11 & 9\end{array}$

Korth, J.

Grupper, A.

Hod, T.

Stumpf, J. (a)

Stumpf, J. (b)

Heterogeneity: $\mathrm{T}^{2}=0.31, \mathrm{I}^{2}=93.55 \%, \mathrm{H}^{2}=15.50$

Test of $\theta_{i}=\theta_{j}: Q(7)=37.18, p=0.00$

\section{Others}

Rabinowich, L. $\quad 38 \quad 42$

Schramm, R. $\quad 5 \quad 45$

Cao, J.

Marinaki, S.

Rashidi-Alavijeh, J.

15

20

Peled, Y.

34

Heterogeneity: $\mathrm{T}^{2}=0.45, \mathrm{I}^{2}=95.05 \%, \mathrm{H}^{2}=20.20$

Test of $\theta_{i}=\theta_{\mathrm{j}}: \mathrm{Q}(5)=58.28, \mathrm{p}=0.00$

\section{Overall}

Heterogeneity: $\mathrm{T}^{2}=0.35, \mathrm{I}^{2}=94.67 \%, \mathrm{H}^{2}=18.76$

Test of $\theta_{\mathrm{i}}=\theta_{\mathrm{j}}: \mathrm{Q}(13)=109.53, \mathrm{p}=0.00$

Test of group differences: $Q_{b}(1)=0.36, p=0.55$

Random-effects REML model

$\begin{array}{rl}39 & \\ 35 & 0 \\ 23 & 0 \\ 25 & 0 \\ 139 & 0 \\ 103 & 2 \\ 39 & 1 \\ 20 & 1 \\ \end{array}$

$0.09[0.03,0.24] \quad 4.90$ 0.04 [ $0.01,0.18] \quad 3.02$ 0.23 [ $0.11,0.49] \quad 6.09$ 0.38 [ $0.31,0.48] \quad 8.24$ 0.44 [ $0.36,0.54$ ] 8.29 $0.50[0.44,0.56] \quad 8.45$ 0.27 [ $0.19,0.37] 7.91$ 0.56 [ $0.38,0.83] 7.66$ 0.30 [ $0.20,0.47$ ]

0.48 [ $0.38,0.61] \quad 8.21$ 0.11 [ $0.05,0.24] \quad 5.84$ 0.43 [ $0.29,0.64] 7.62$ 0.59 [ $0.45,0.78] \quad 8.08$ 0.80 [ $0.68,0.95] \quad 8.37$ 0.18 [ $0.11,0.30] 7.32$

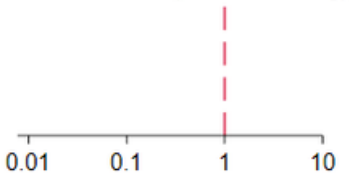

Figure 4

Meta-analysis of seroconversion in transplant patients vs controls, based on type of transplant

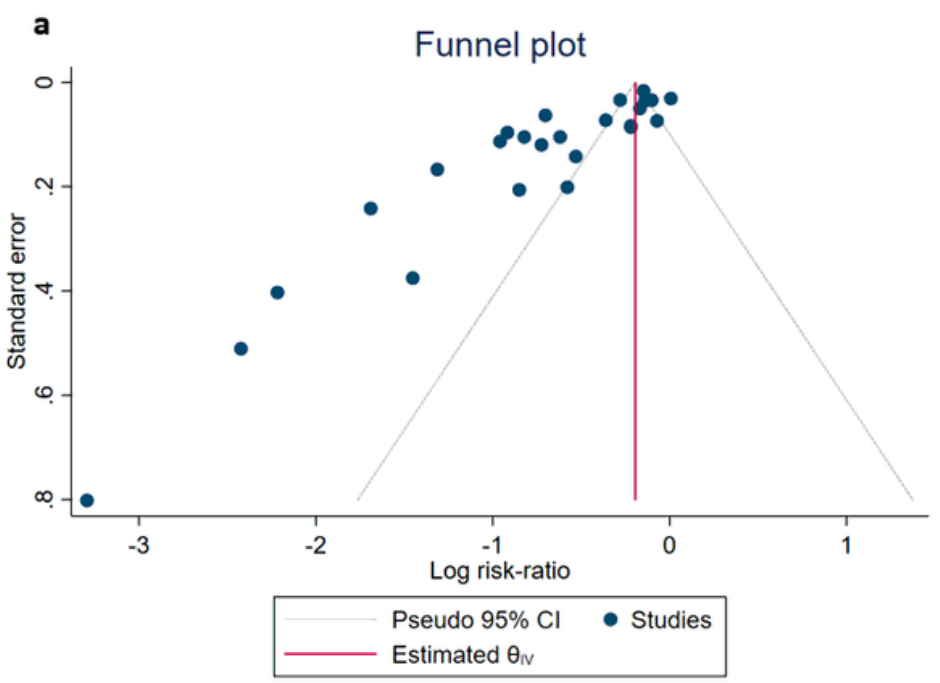

b

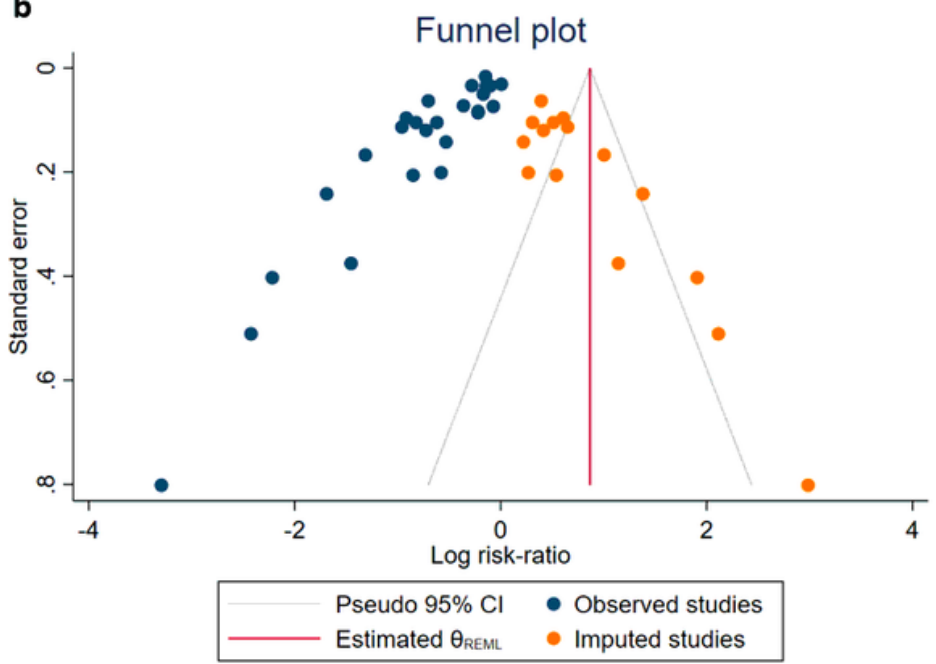

Figure 5

Funnel plot (a) and trim and fill funnel plot (b) for meta-analysis of seroconversion in patients with immunodeficiency

\section{Supplementary Files}

This is a list of supplementary files associated with this preprint. Click to download.

- Additionalfile1.docx 